\title{
Acortatarins A and B, Two Novel Antioxidative Spiroalkaloids with a Naturally Unusual Morpholine Motif from Acorus tatarinowii
}

Xiao-Gang Tong, Li-Li Zhou, Yue-Hu Wang, Cheng-Feng Xia, Ye Wang, Min Liang, Fan-Fan Hou, and Yong-Xian Cheng ${ }^{*}$

State Key Laboratory of Phytochemistry and Plant Resources in West China, Kunming Institute of Botany, Chinese Academy of Sciences, Kunming 650204, Yunnan, PRC, Graduate School of Chinese Academy of Sciences, Beijing 100039, PRC, Division of Nephrology, Nanfang Hospital, Southern Medical University, Key Laboratory for Organ Failure Research, Education Ministry, Guangzhou, 510515, Guangdong, PRC, and The Key Laboratory of Chemistry for Natural Products of Guizhou Province and Chinese Academy of Sciences, Guiyang 550002, Guizhou, PRC

yxcheng@mail.kib.ac.cn (Y.X.C); ffhou@pub.guangzhou.gd.cn (F.F.H)

\section{Supporting Information}

S1. Experimental Section

S2. ${ }^{1} \mathrm{H}$ NMR spectrum of acortatarin $\mathrm{A}(\mathbf{1})$ in $\mathrm{CD}_{3} \mathrm{OD}$

S3. $\quad{ }^{13} \mathrm{C}$ NMR spectrum of acortatarin $\mathrm{A}(\mathbf{1})$ in $\mathrm{CD}_{3} \mathrm{OD}$

S4. $\quad{ }^{1} \mathrm{H}-{ }^{1} \mathrm{H}$ COSY spectrum of acortatarin $\mathrm{A}(\mathbf{1})$ in $\mathrm{CD}_{3} \mathrm{OD}$

S5. HSQC spectrum of acortatarin $\mathrm{A}(\mathbf{1})$ in $\mathrm{CD}_{3} \mathrm{OD}$

S6. $\mathrm{HMBC}$ spectrum of acortatarin $\mathrm{A}(\mathbf{1})$ in $\mathrm{CD}_{3} \mathrm{OD}$

S7. FABMS spectrum of acortatarin A (1)

S8. IR spectrum of acortatarin A (1)

S9. $\quad{ }^{1} \mathrm{H}$ NMR spectrum of acortatarin $\mathrm{B}(2)$ in $\mathrm{CD}_{3} \mathrm{OD}$

S10. $\quad{ }^{13} \mathrm{C}$ NMR spectrum of acortatarin $\mathrm{B}(2)$ in $\mathrm{CD}_{3} \mathrm{OD}$

S11. $\quad{ }^{1} \mathrm{H}-{ }^{1} \mathrm{H}$ COSY spectrum of acortatarin $\mathrm{B}(2)$ in $\mathrm{CD}_{3} \mathrm{OD}$ 
S12. HSQC spectrum of acortatarin $\mathrm{B}(2)$ in $\mathrm{CD}_{3} \mathrm{OD}$

S13. HMBC spectrum of acortatarin $\mathrm{B}(2)$ in $\mathrm{CD}_{3} \mathrm{OD}$

S14. ROESY spectrum of acortatarin $\mathrm{B}(2)$ in $\mathrm{CD}_{3} \mathrm{OD}$

S15. FABMS spectrum of acortatarin B (2)

S16. IR spectrum of acortatarin B (2)

S17. $\quad{ }^{1} \mathrm{H}$ NMR spectrum of $\mathbf{1 a}$ in $\mathrm{CDCl}_{3}$

S18. $\quad{ }^{1} \mathrm{H}$ NMR spectrum of $(S)$-MTPA ester of $\mathbf{1 a}$ in $\mathrm{CDCl}_{3}$

S19. $\quad{ }^{1} \mathrm{H}-{ }^{1} \mathrm{H}$ COSY spectrum of $(S)$-MTPA ester of $\mathbf{1 a}$ in $\mathrm{CDCl}_{3}$

S20. $\quad{ }^{1} \mathrm{H}$ NMR spectrum of (R)-MTPA ester of $\mathbf{1 a}$ in $\mathrm{CDCl}_{3}$

S21. ${ }^{1} \mathrm{H}-{ }^{1} \mathrm{H}$ COSY spectrum of $(R)$-MTPA ester of $\mathbf{1 a}$ in $\mathrm{CDCl}_{3}$ 


\section{S1. Experimental Section}

General Experimental Procedures. Melting points were measured on an SGW X-4 melting instrument and uncorrected. Optical rotations were measured using a Horiba SEPA-300 polarimeter. UV spectra were recorded on a Shimadzu UV-2401PC spectrophotometer. IR spectra were obtained on a Tensor 27 with $\mathrm{KBr}$ pellets. NMR spectra were recorded on a Bruker AV-400 or a DRX-500 spectrometer with TMS as an internal standard. FABMS were measured on a VG Autospec-3000 spectrometer. HRESIMS were determined with an API QSTAR Pulsar 1 spectrometer. Silica gel (200-300 mesh, Qingdao Marine Chemical Co. Ltd., P.R. China), MCI gel CHP 20P, 75-150 $\mu \mathrm{M}$, Mitsubishi Chemical Industries Ltd.), RP-18 (40-63 $\mu \mathrm{m}$, Daiso Co., Japan), and Sephadex LH-20 (Amersham Biosciences, Sweden) were used for column chromatography. Semi-preparative HPLC (Agilent 1100 HPLC system, Zorbax SB-C-18, Agilent, $9.4 \mathrm{~mm} \times 25 \mathrm{~cm}$ ). Spots on TLC plates were detected under UV radiation and by heating after spraying with $10 \% \mathrm{H}_{2} \mathrm{SO}_{4}$ in $\mathrm{EtOH}$.

Plant Material: The rhizome of $A$. tatarinowii was purchased from Yunnan Corporation of Materia Medica (YCMM), Yunnan Province, P.R. China, and identified by Mr. Hong-Yan Sun, at YCMM. A voucher specimen (CHYX0001) was deposited at the State Key Laboratory of Phytochemistry and Plant Resources in West China, Kunming Institute of Botany, CAS, P.R. China.

Extraction and Isolation: The air-dried powders of A. tatarinowii rhizome (50 kg) 
were extracted with boiling water $(2 \times 100 \mathrm{~L})$ and then EtOH $(1 \times 100 \mathrm{~L})$ under reflux to give an extract $(4.7 \mathrm{~kg})$, which was suspended in water $(6 \mathrm{~L})$ followed by exhaustive partition with EtOAc and $n$ - $\mathrm{BuOH}$. The $n$ - $\mathrm{BuOH}$ soluble extract (315 g) was separated by silica gel column chromatography eluted with gradient $\mathrm{CHCl}_{3}$ $\mathrm{MeOH}-\mathrm{H}_{2} \mathrm{O}$ to supply eight fractions (I - VIII). The fraction IV (9.3 g) was passed through a MCI gel CHP 20P column with gradient aqueous $\mathrm{MeOH}$ to yield four sub-fractions (IV-A - IV-D). The sub-fraction IV-B (1.6 g) was purified by $\mathrm{C}_{18}$ silica gel, Sephadex LH-20 and semi-preparative HPLC (Agilent 1100 HPLC system, Zorbax SB-C-18, Agilent, $9.4 \mathrm{~mm} \times 25 \mathrm{~cm}, \mathrm{MeOH}-\mathrm{H}_{2} \mathrm{O}, 20: 80$ ) to afford compounds $\mathbf{1}(7.3 \mathrm{mg})$ and $\mathbf{2}(3.4 \mathrm{mg})$.

\section{Preparation of $(S)$ - and $(R)$-Mosher esters of 1:}

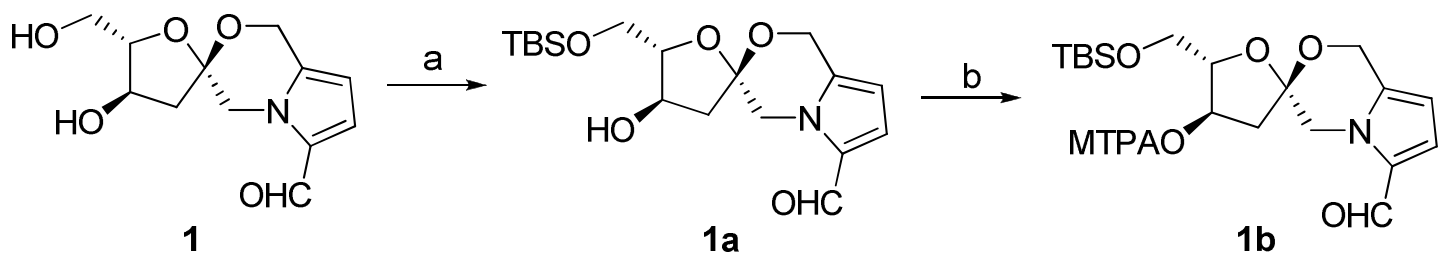

(a) $\mathrm{BuMe}_{2} \mathrm{SiCl}, \mathrm{Et}_{3} \mathrm{~N}$, DMAP, $\mathrm{CH}_{2} \mathrm{Cl}_{2}$; (b) MTPA-Cl, Et 3 N, DMAP, $\mathrm{CH}_{2} \mathrm{Cl}_{2}$.

(a) To a solution of acortatarin A (1) $(5.3 \mathrm{mg}, 0.021 \mathrm{mmol})$ and anhydrous $\mathrm{Et}_{3} \mathrm{~N}$ (4 $\mu \mathrm{L}, 0.03 \mathrm{mmol})$ in dry $\mathrm{CH}_{2} \mathrm{Cl}_{2}(1 \mathrm{~mL})$ cooled at $-10{ }^{\circ} \mathrm{C}$ was added $\mathrm{BuMe}_{2} \mathrm{SiCl}(3.8$ $\mathrm{mg}, 0.025 \mathrm{mmol})$. The reaction mixture was stirred for $8 \mathrm{~h}$ and then was allowed to be warmed to room temperature over $6 \mathrm{~h}$. $\mathrm{MeOH}(10 \mu \mathrm{L})$ was added to quench the reaction and mixture was continued stirring for additional $30 \mathrm{~min}$. The solvent was removed under reduced pressure. The residue was purified by silica gel column chromatography (petroleum/ethyl acetate, 4:1) to give $2.9 \mathrm{mg}$ of product, and recover 
$1.9 \mathrm{mg}$ of the acortatarin A.

(b) The above product $(2.9 \mathrm{mg}, 0.0079 \mathrm{mmol})$ was divided into two portions, which were dissolved in dry $\mathrm{CH}_{2} \mathrm{Cl}_{2}(0.5 \mathrm{~mL}) . \mathrm{Et}_{3} \mathrm{~N}(2 \mu \mathrm{L}, 0.016 \mathrm{mmol})$ and catalytic amount of DMAP were added, followed by $(R)$ - or (S)- $\alpha$-methoxy- $\alpha$-(trifluoromethyl)phenylacetyl chloride (MTPA-Cl) (1.2 $\mu \mathrm{L}$, $0.0063 \mathrm{mmol}$ ). The reaction mixture was stirred at room temperature until TLC showed all the starting material was consumed. The mixture was evaporated to removed the organic solvent and the residue was purified by silica gel column chromatography (petroleum/ethyl acetate, 10:1) to afford $0.8 \mathrm{mg}(R)$-MTPA and $1.2 \mathrm{mg}(S)$-MTPA esters, respectively.

\section{X-ray crystal data and structure refinement for acortatarin A (1):}

Empirical formula

Formula weight

Temperature

Wavelength

Crystal system

Space group

Unit cell dimensions

Volume

$$
\mathrm{C}_{12} \mathrm{H}_{15} \mathrm{NO}_{5}
$$

253.25

293(2) K

0.71073 A

Monoclinic

P2(1)

$$
\begin{aligned}
& a=7.2060(11) \AA, \alpha=90^{\circ} \\
& b=7.0551(11) \AA, \beta=97.86(3)^{\circ} \\
& c=11.5524(17) \AA, \gamma=90^{\circ}
\end{aligned}
$$

$581.80(15) \AA^{3}$ 
Calculated density

Absorption coefficient

F (000)

Crystal size

Theta range for data collection

Limiting indices

Reflections collected / unique

Completeness to theta $=26.00$

Absorption correction

Refinement method

Data / restraints / parameters

Goodness-of-fit on $\mathrm{F}^{2}$

Final $R$ indices $[\mathrm{I}>2 \sigma(\mathrm{I})]$

$\mathrm{R}$ indices (all data)

Absolute structure parameter

Largest diff. peak and hole
$1.446 \mathrm{Mg} / \mathrm{m}^{3}$

$0.113 \mathrm{~mm}^{-1}$

268

$0.299 \times 0.187 \times 0.101 \mathrm{~mm}^{3}$

2.85 to $25.99^{\circ}$

$-7<=\mathrm{h}<=8,-8<=\mathrm{k}<=8,-12<=\mathrm{l}<=14$

$3200 / 1237[\mathrm{R}($ int $)=0.0458]$

$99.4 \%$

\section{Empirical}

Full-matrix least-squares on $\mathrm{F}^{2}$

1237 / 1 / 166

1.046

$\mathrm{R} 1=0.0403, \mathrm{wR} 2=0.1057$

$\mathrm{R} 1=0.0417, \mathrm{wR} 2=0.1068$

10(10)

0.195 and -0.169 e. $\AA^{-3}$

Colorless crystals of $\mathbf{1}$ were obtained in $\mathrm{MeOH}$. Crystal data were collected on a Bruker SMART CCD detector employing graphite monochromated Mo-Ka radiation $(\lambda=0.71073 \AA)$ at $293(2) \mathrm{K}$ and operating in the $\varphi-\omega$ scan mode. The structure was solved by direct methods SHELXS- $97^{1}$ and refined with full-matrix least-squares calculations on $F^{2}$ using SHELX-97. ${ }^{2}$ All non-hydrogen atoms were refined 
anisotropically. The hydrogen atom positions were geometrically idealized and allowed to ride on their parent atoms. Crystallographic data for $\mathbf{1}$ have been deposited at the Cambridge Crystallographic Data Centre (deposition no. CCDC-760186). Copies of these data can be obtained free of charge via www.ccdc.cam.ac.uk/conts/retrieving.html (or from the Cambridge Crystallographic Data Centre, 12, Union Road, Cambridge CB21EZ, UK; fax: (+44) 1223-336-033; email: deposit@ccdc.cam.ac.uk).

\section{References:}

(1) Sheldrick, G. M. SHELXS-97: Program for X-ray Crystal Structure Solution; University of Göttingen: Göttingen, Germany, 1997.

(2) Sheldrick, G. M. SHELX-97: Program for X-ray Crystal Structure Refinement; University of Göttingen: Göttingen, Germany, 1997. 
S2. ${ }^{1} \mathrm{H}$ NMR spectrum of acortatarin $\mathrm{A}(\mathbf{1})$ in $\mathrm{CD}_{3} \mathrm{OD}$
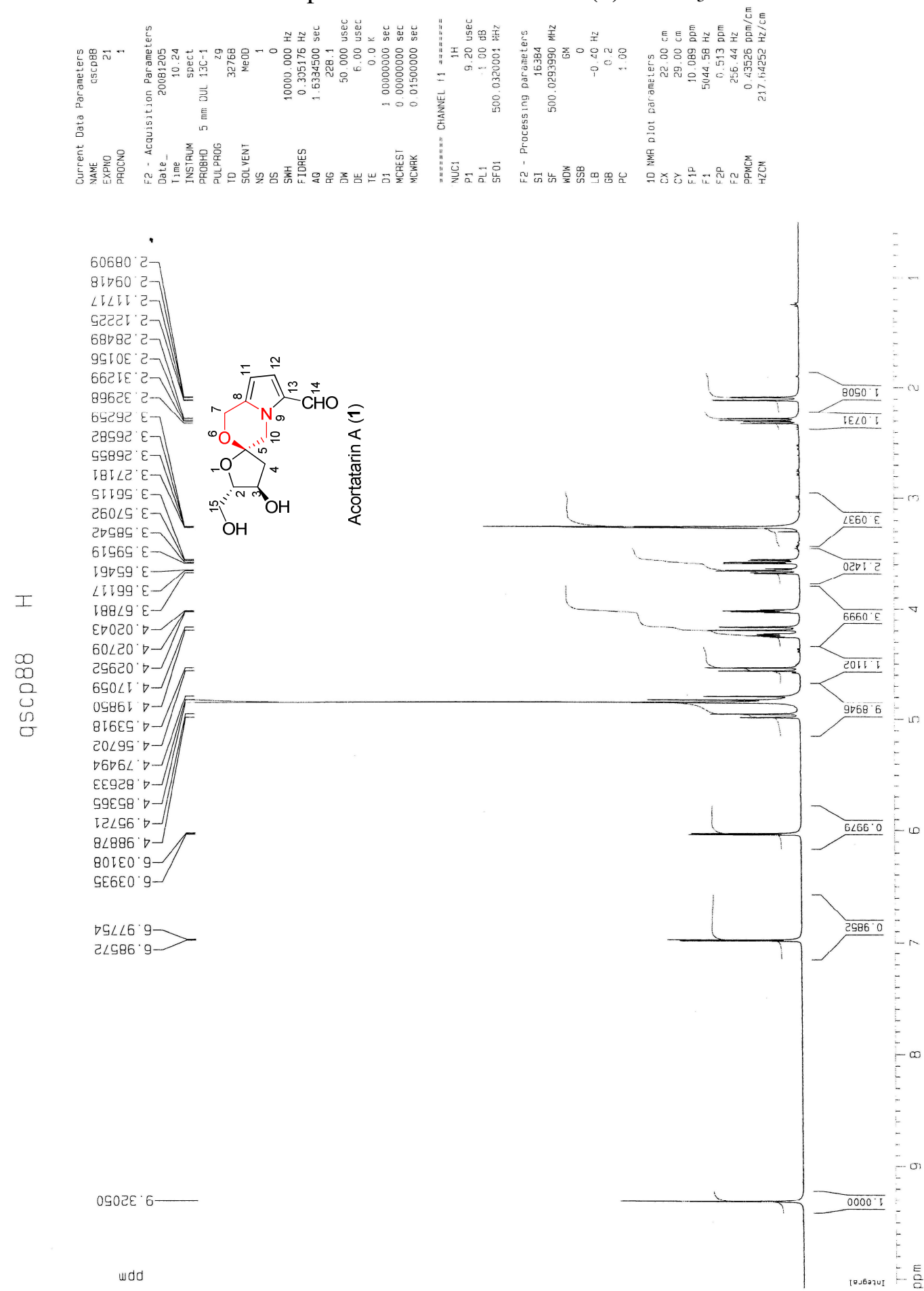
S3. ${ }^{13} \mathrm{C}$ NMR spectrum of acortatarin $\mathrm{A}(\mathbf{1})$ in $\mathrm{CD}_{3} \mathrm{OD}$

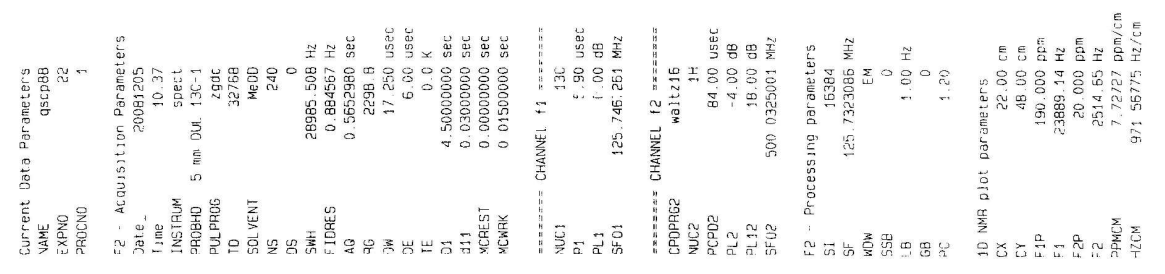

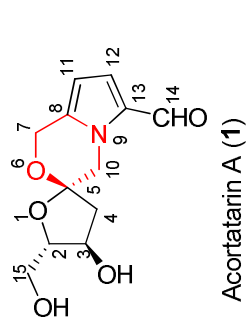

$\stackrel{m}{\mathrm{~s}}$

$\infty$
$\infty$
0
0
0
0

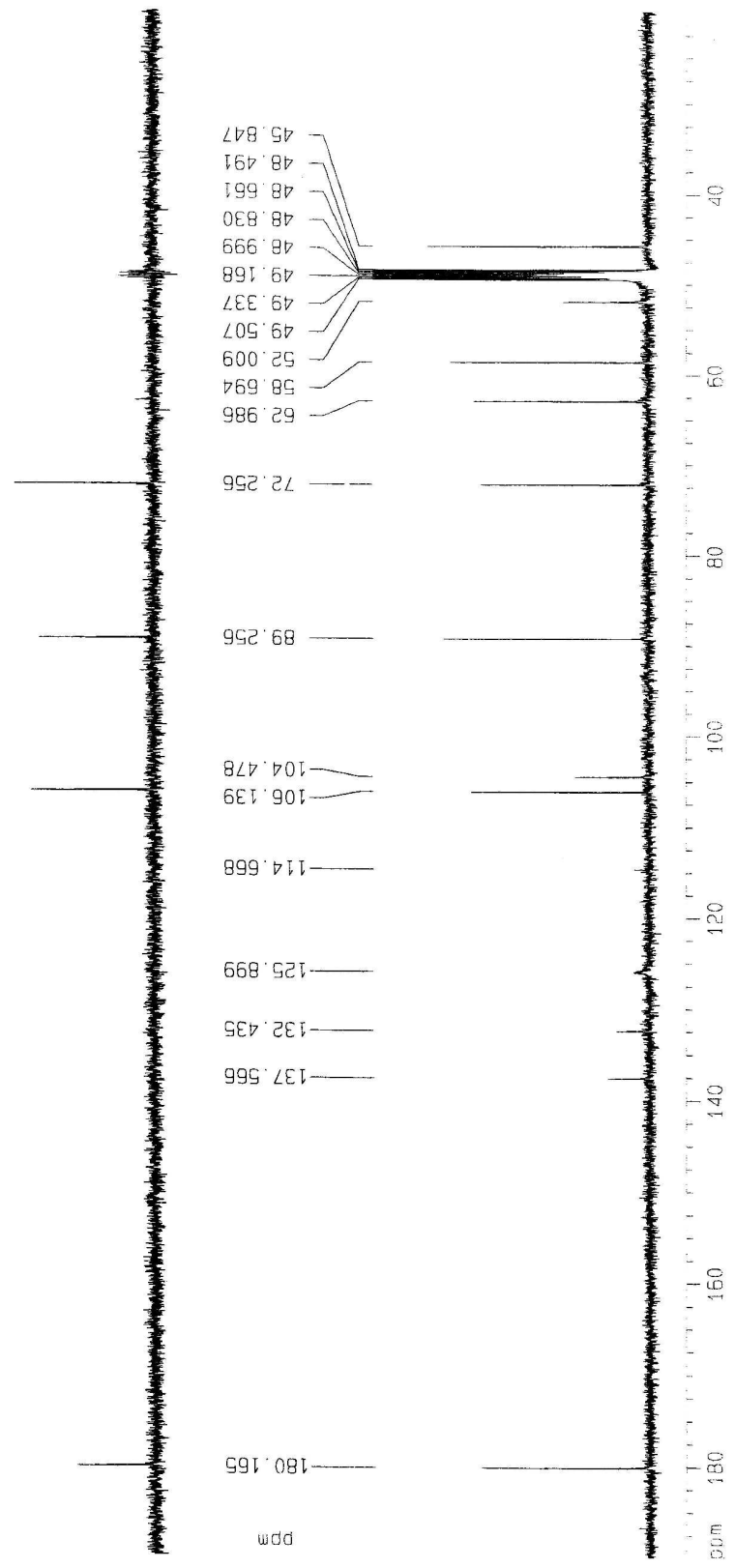



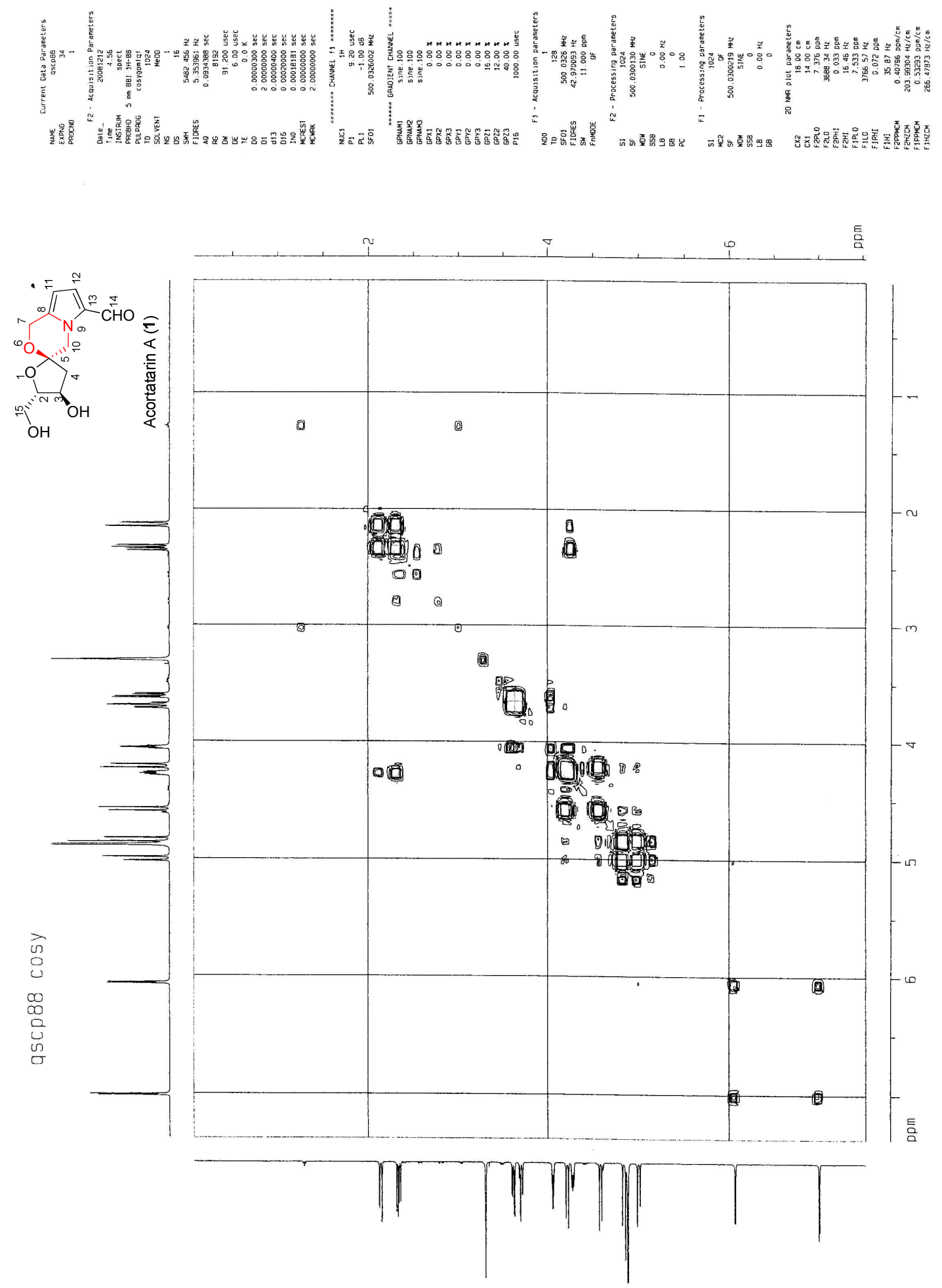
S5. $\mathrm{HSQC}$ spectrum of acortatarin $\mathrm{A}(\mathbf{1})$ in $\mathrm{CD}_{3} \mathrm{OD}$

In

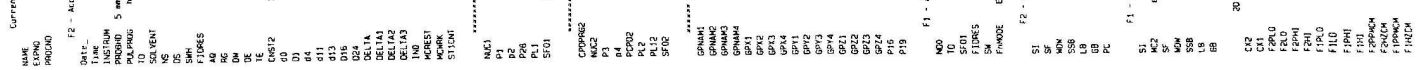

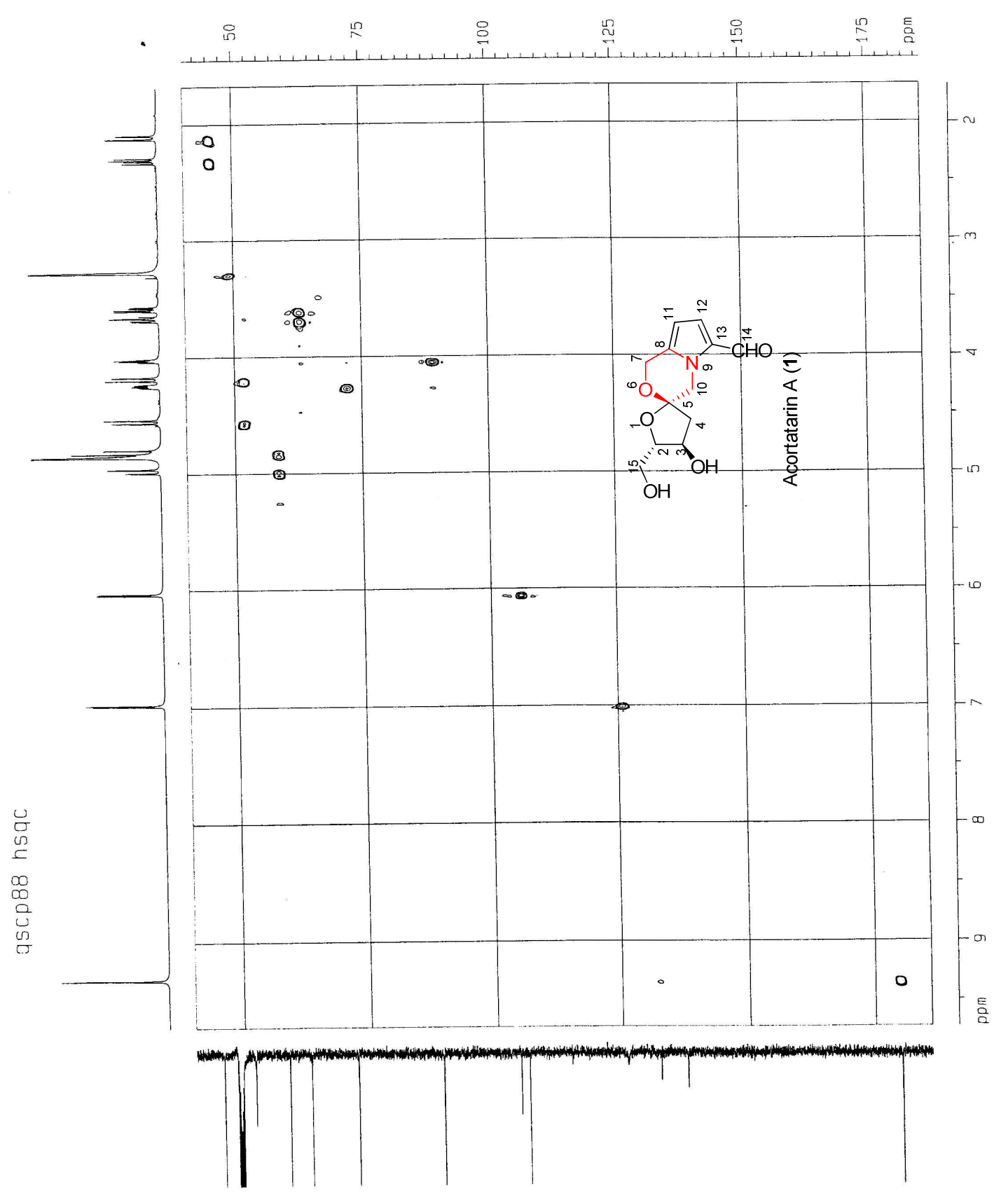


S6. $\mathrm{HMBC}$ spectrum of acortatarin $\mathrm{A}(\mathbf{1})$ in $\mathrm{CD}_{3} \mathrm{OD}$

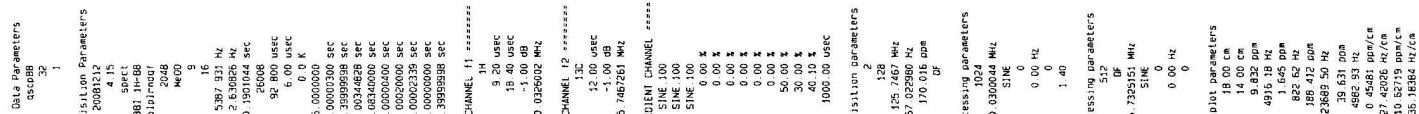
管

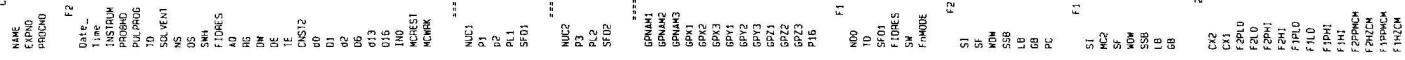

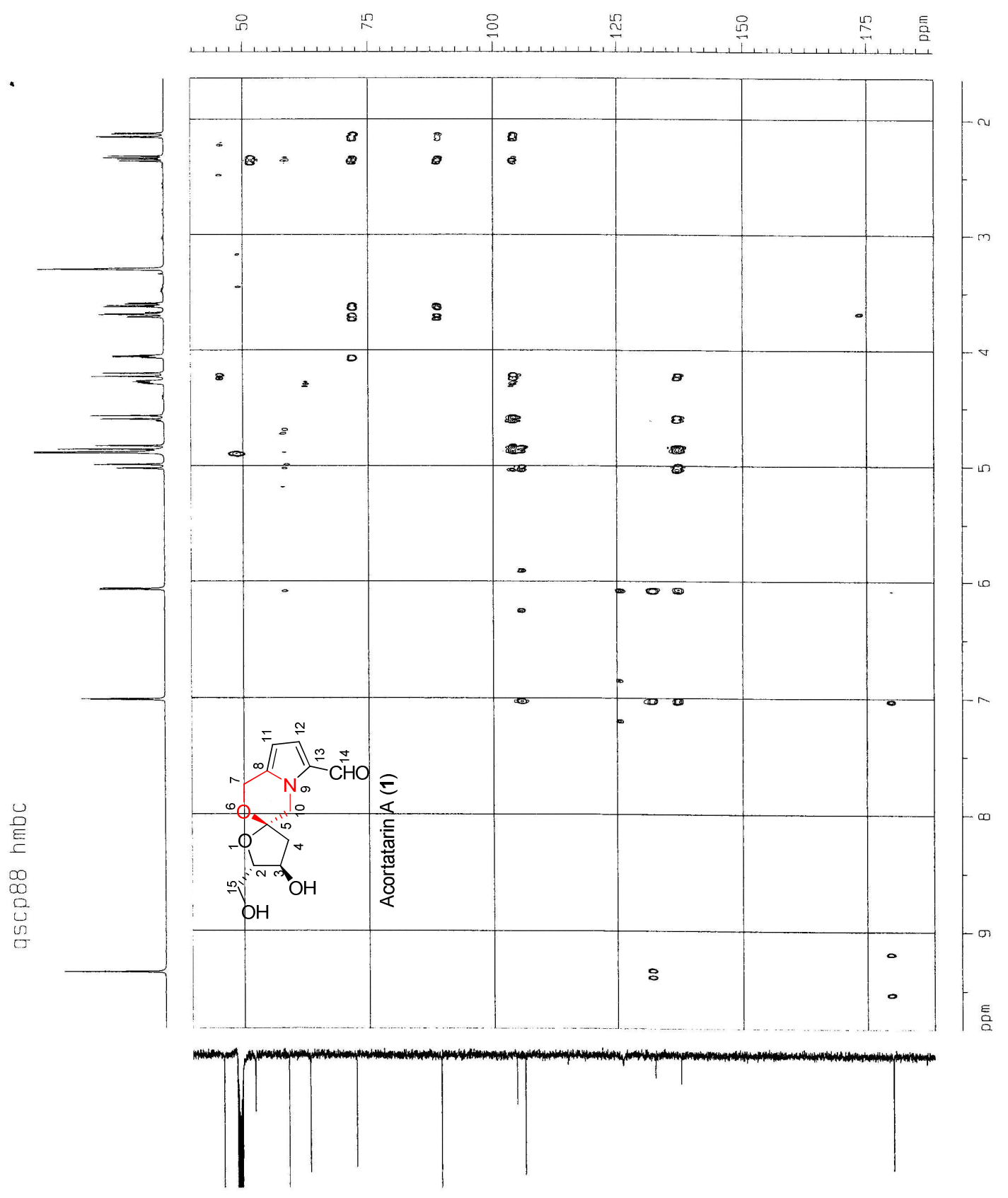


S7. FABMS spectrum of acortatarin A (1)

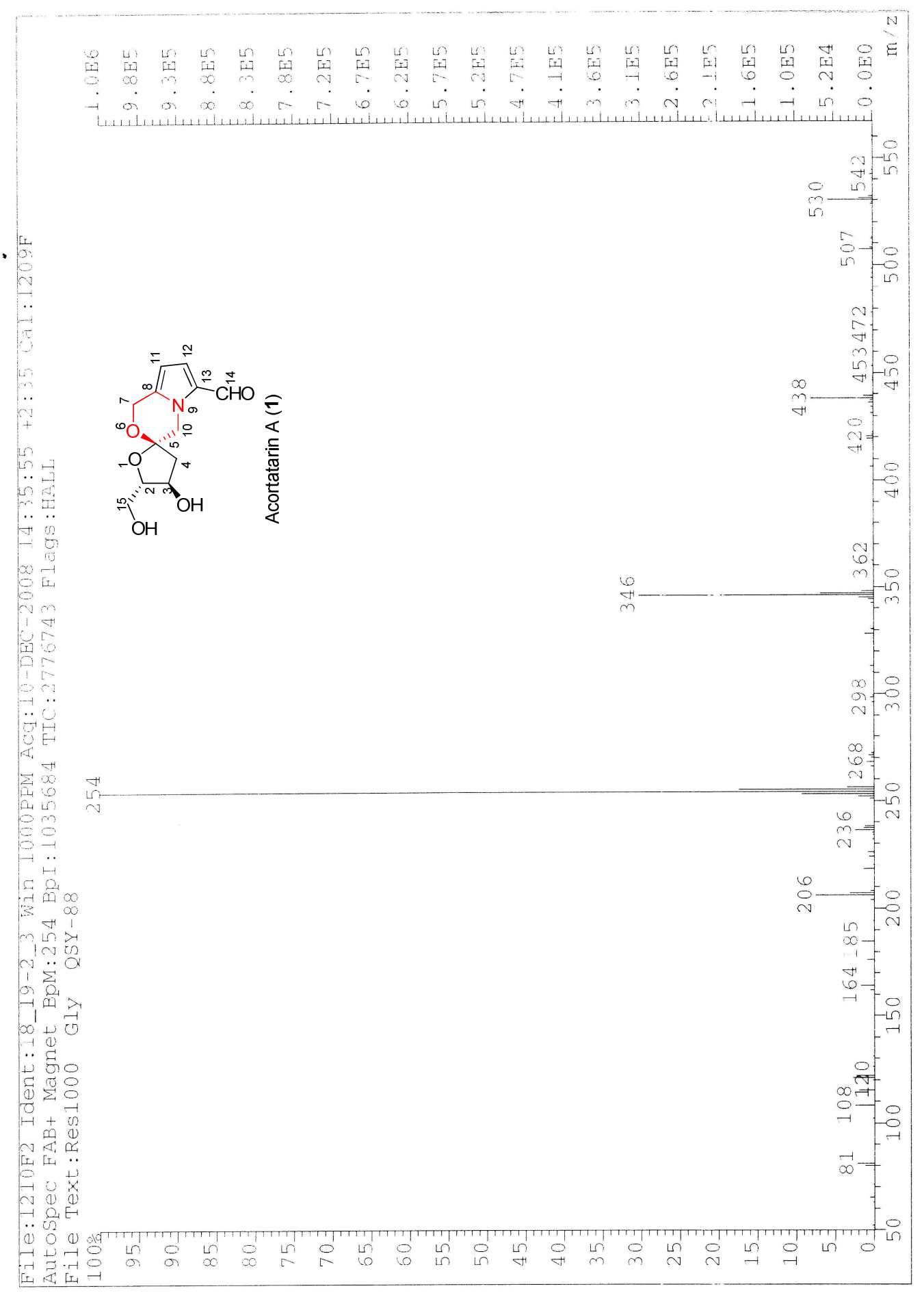


S8. IR spectrum of acortatarin A (1)

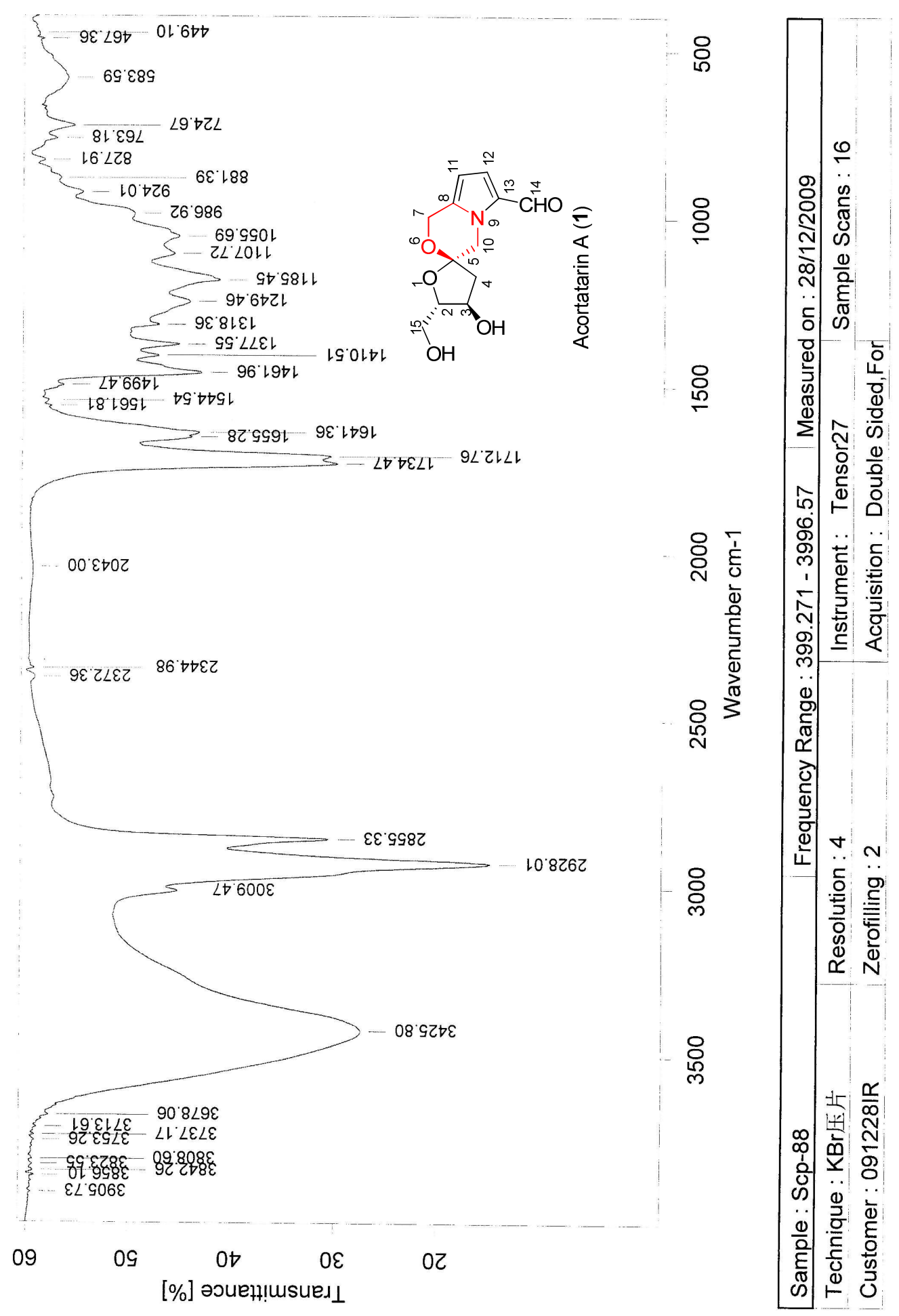




\section{S9. ${ }^{1} \mathrm{H}$ NMR spectrum of acortatarin $\mathrm{B}(2)$ in $\mathrm{CD}_{3} \mathrm{OD}$}
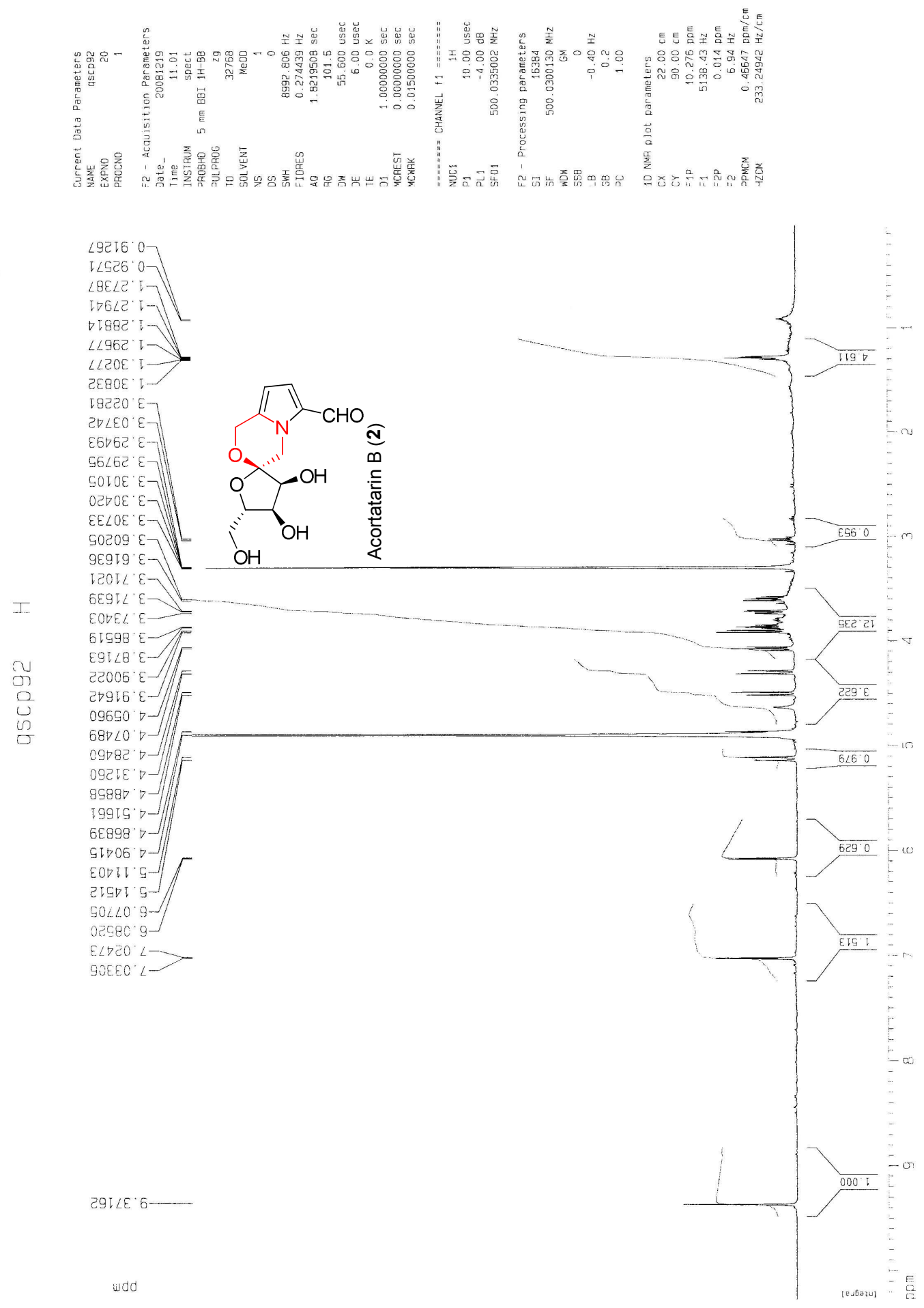
S10. ${ }^{13} \mathrm{C}$ NMR spectrum of acortatarin $\mathrm{B}(2)$ in $\mathrm{CD}_{3} \mathrm{OD}$
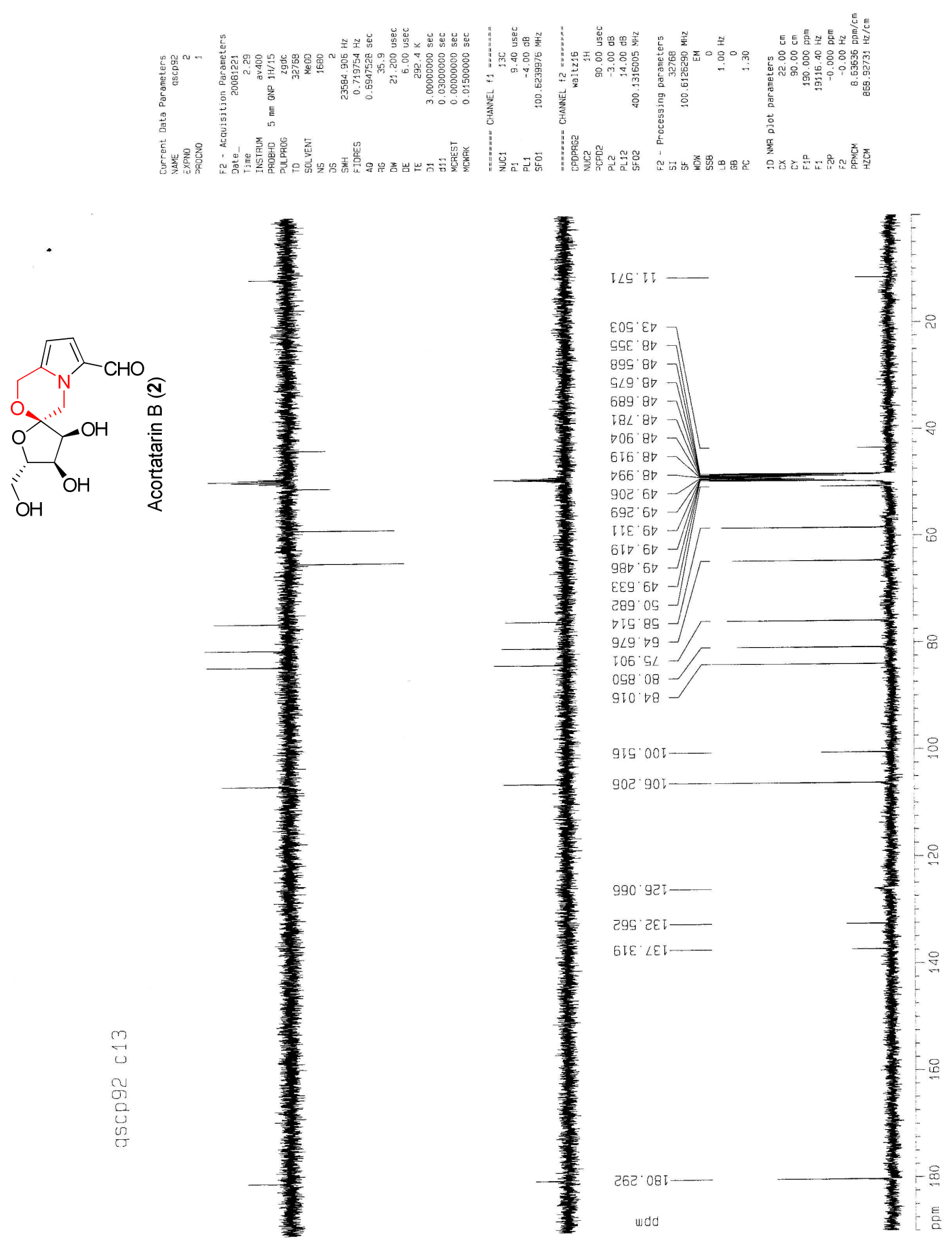
S11. ${ }^{1} \mathrm{H}-{ }^{1} \mathrm{H}$ COSY spectrum of acortatarin $\mathrm{B}(2)$ in $\mathrm{CD}_{3} \mathrm{OD}$
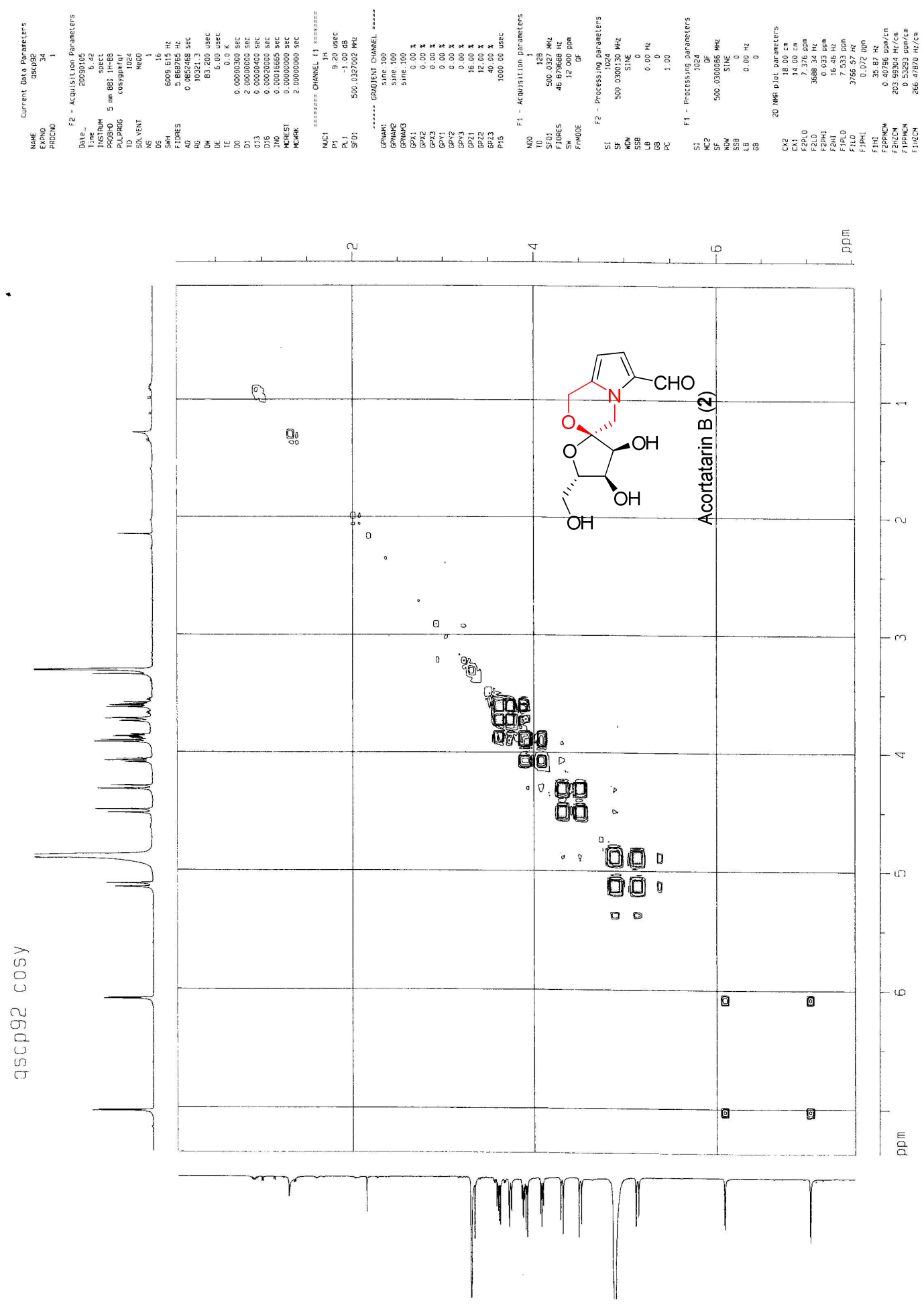
S12. HSQC spectrum of acortatarin $\mathrm{B}(2)$ in $\mathrm{CD}_{3} \mathrm{OD}$

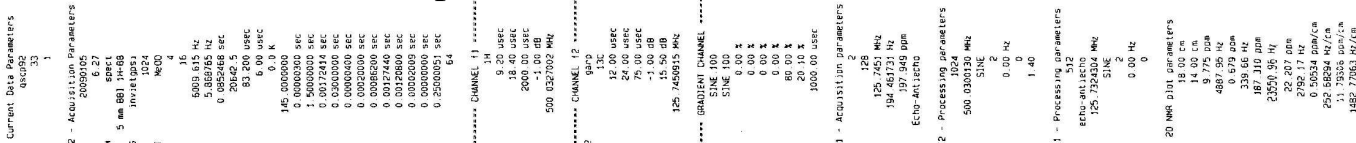

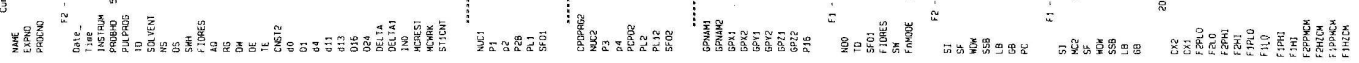

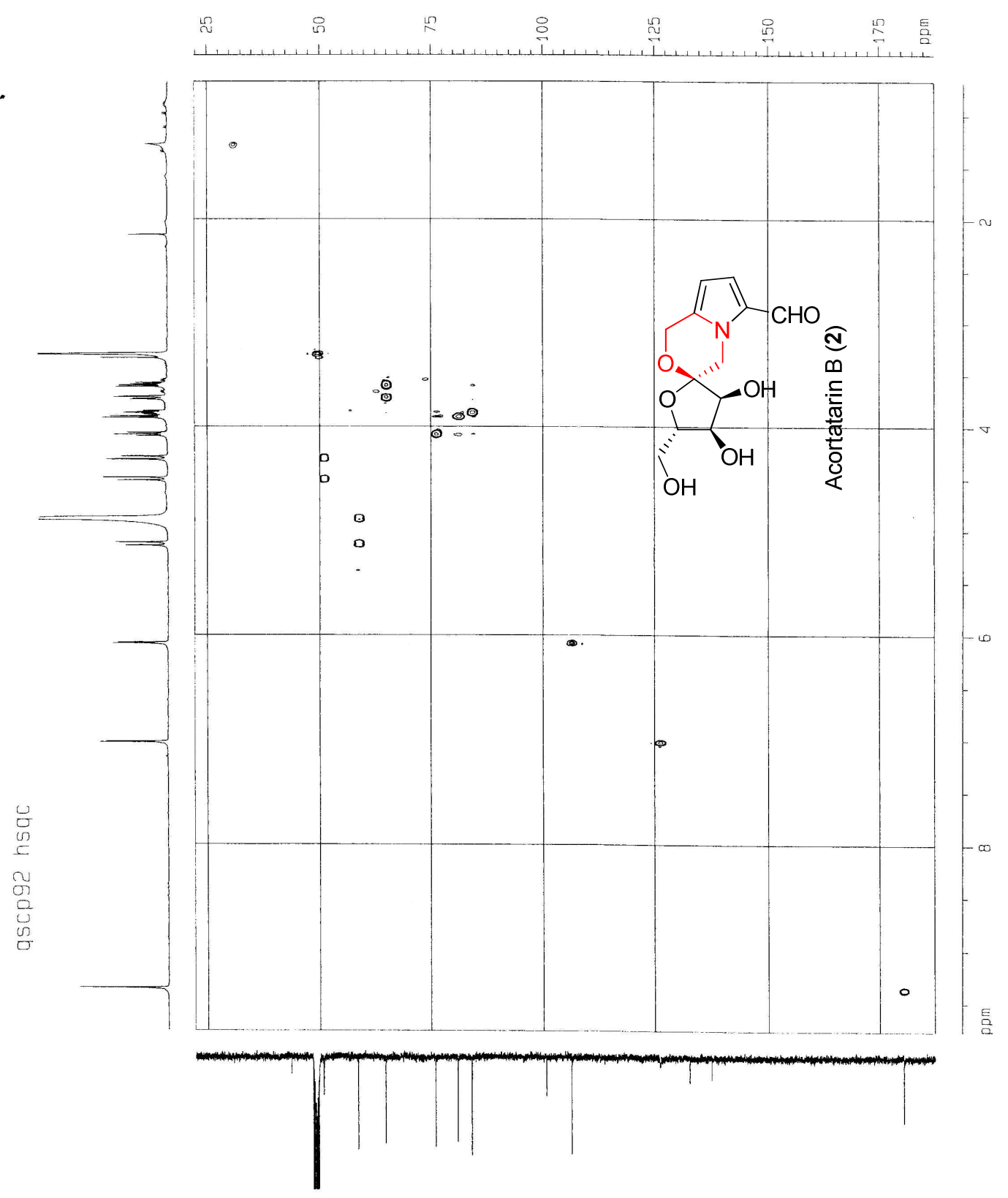


S13. $\mathrm{HMBC}$ spectrum of acortatarin $\mathrm{B}(2)$ in $\mathrm{CD}_{3} \mathrm{OD}$
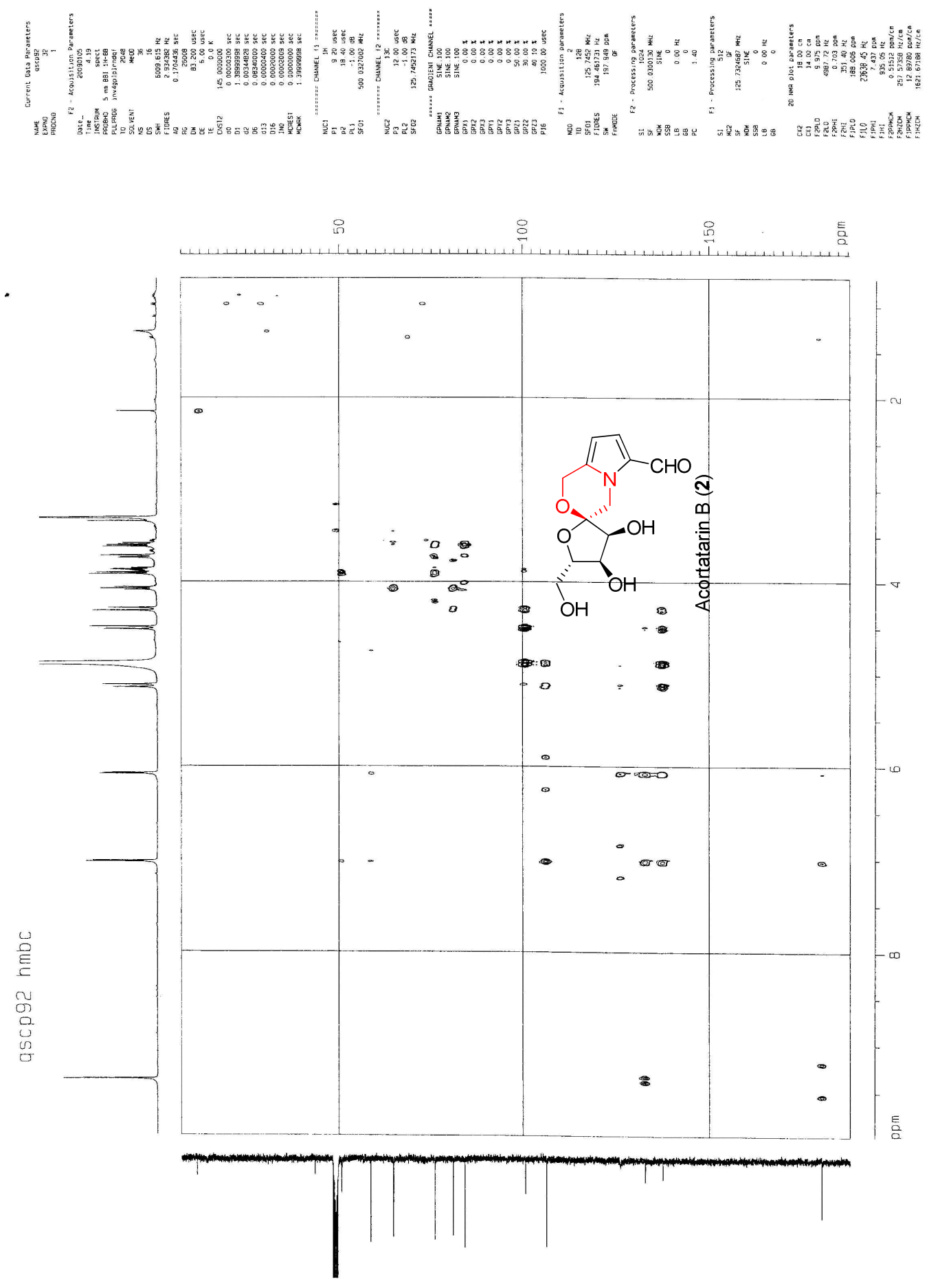
S14. ROESY spectrum of acortatarin $\mathrm{B}(2)$ in $\mathrm{CD}_{3} \mathrm{OD}$
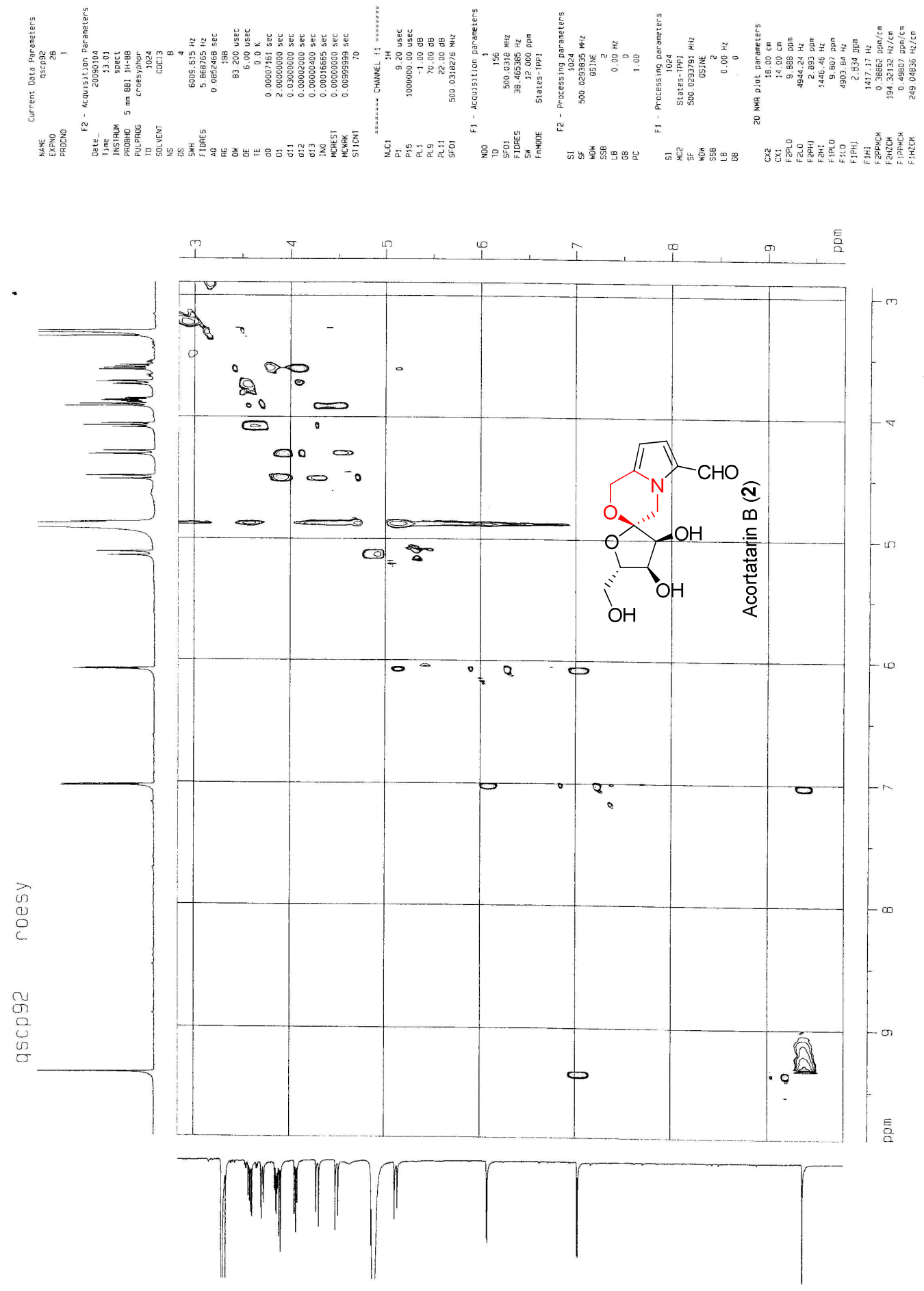
S15. FABMS spectrum of acortatarin B (2)

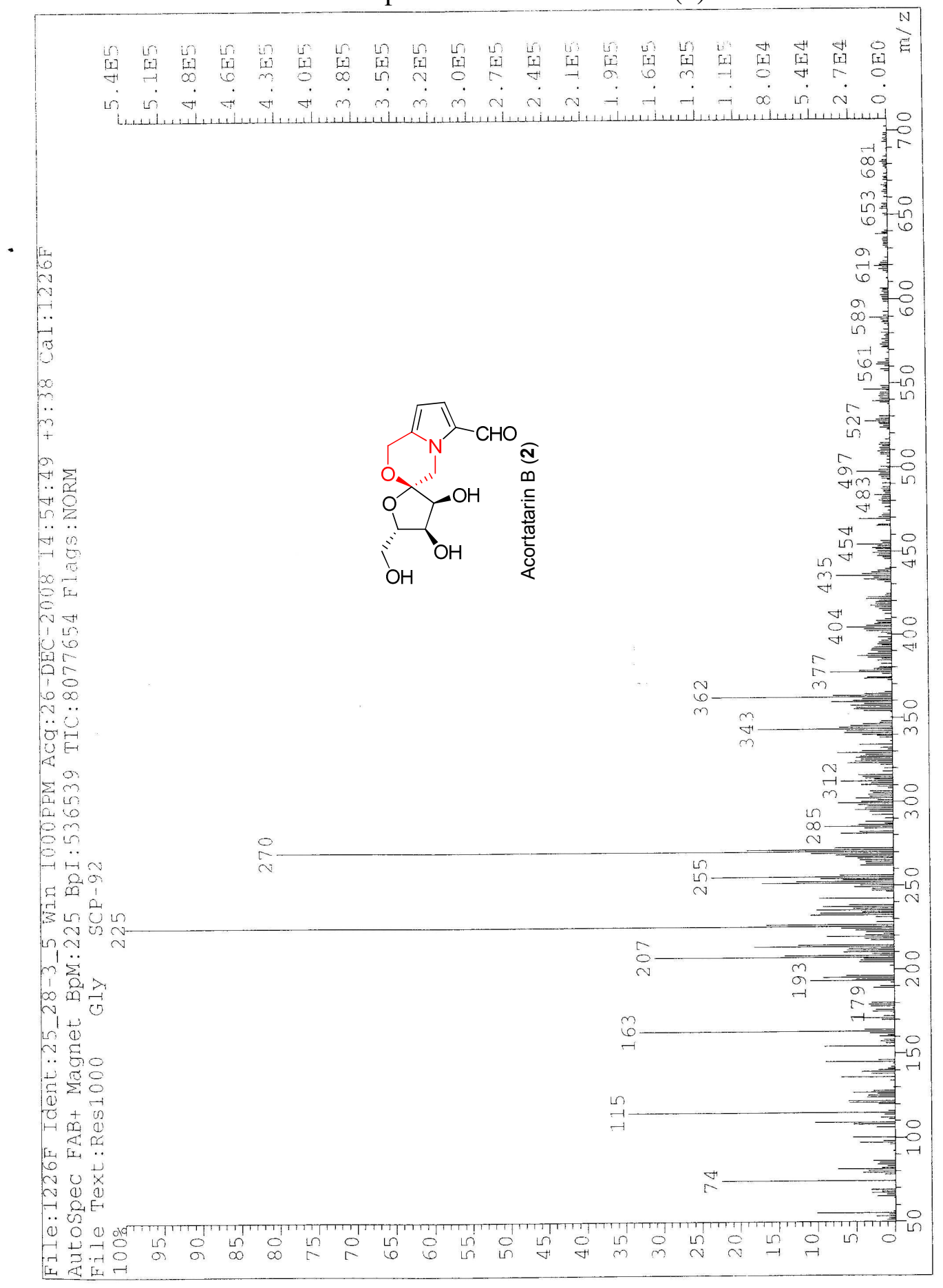


S16. IR spectrum of acortatarin B (2)

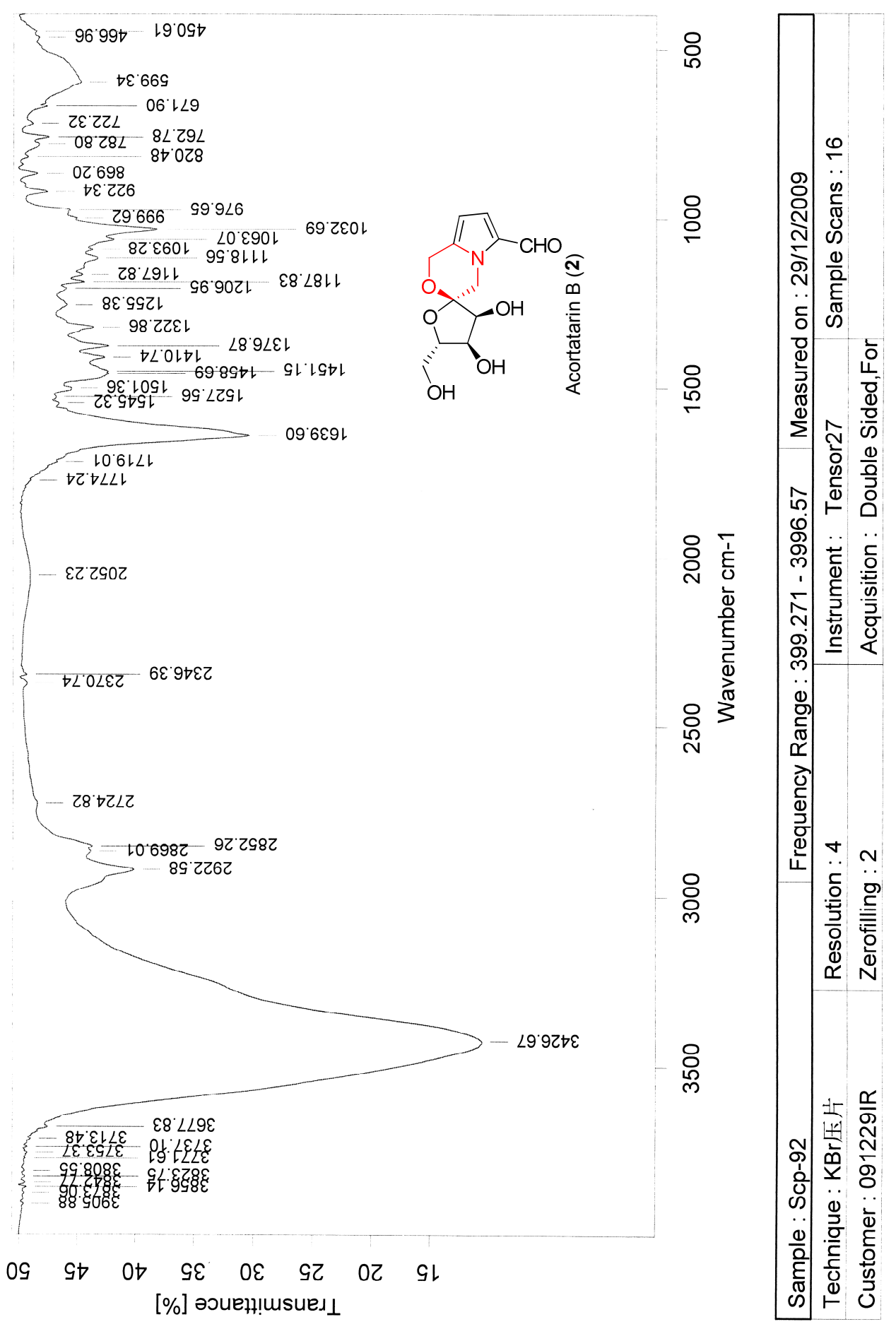




\section{S17. ${ }^{1} \mathrm{H}$ NMR spectrum of $1 \mathbf{a}$ in $\mathrm{CDCl}_{3}$}
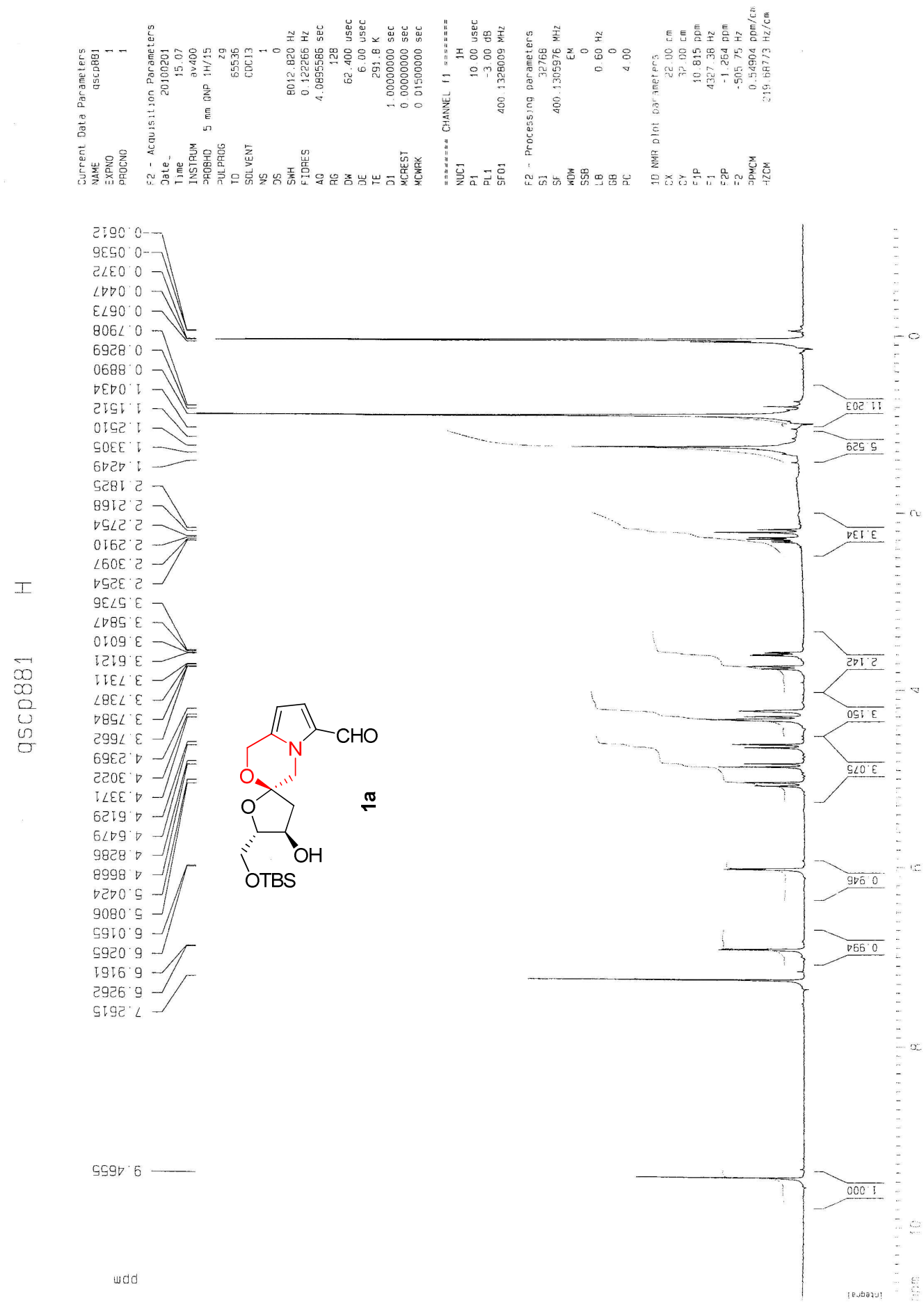
S18. $\quad{ }^{1} \mathrm{H}$ NMR spectrum of $(S)$-MTPA ester of $\mathbf{1 a}$ in $\mathrm{CDCl}_{3}$
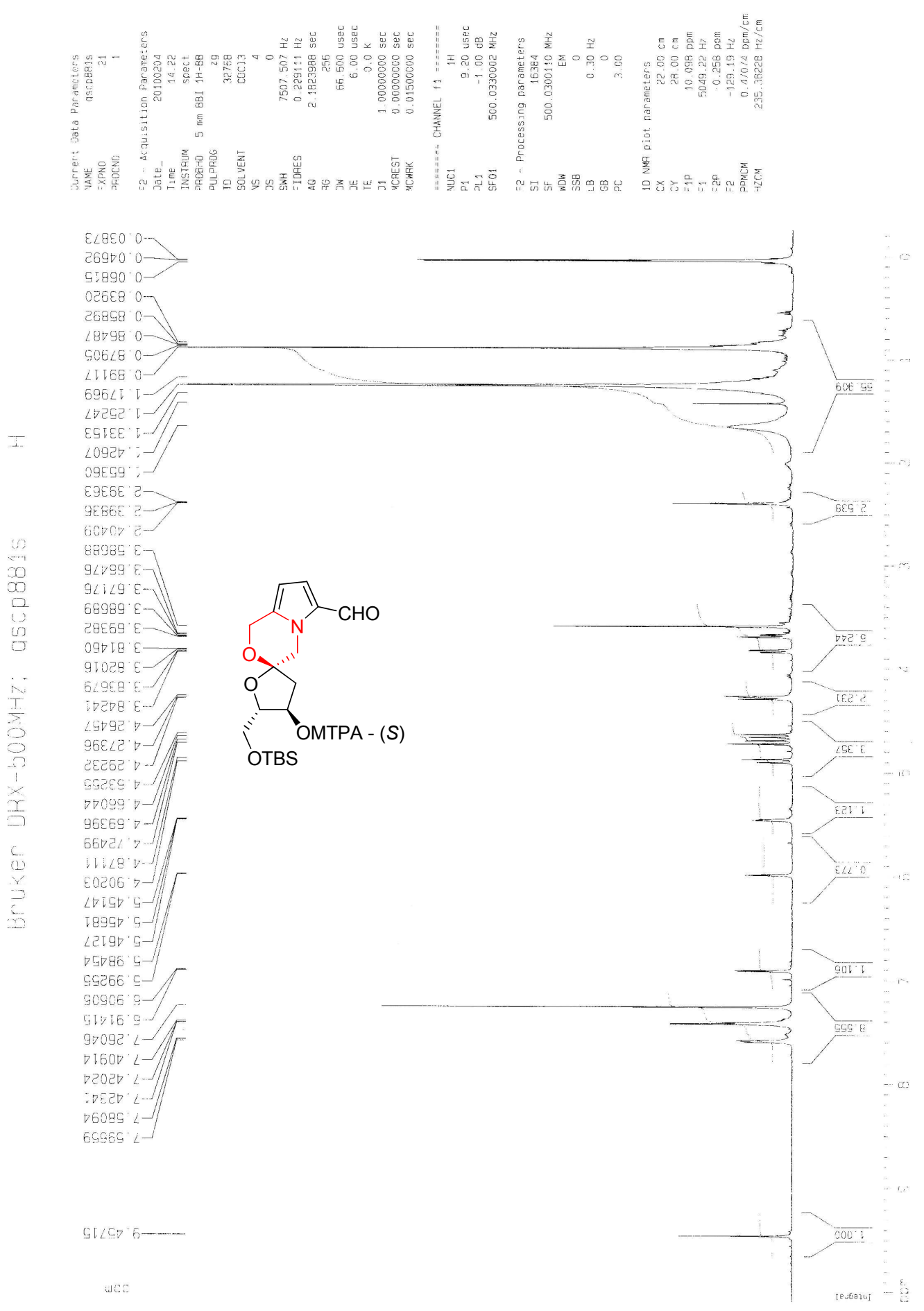
S19. ${ }^{1} \mathrm{H}-{ }^{1} \mathrm{H}$ COSY spectrum of (S)-MTPA ester of $\mathbf{1 a}$ in $\mathrm{CDCl}_{3}$
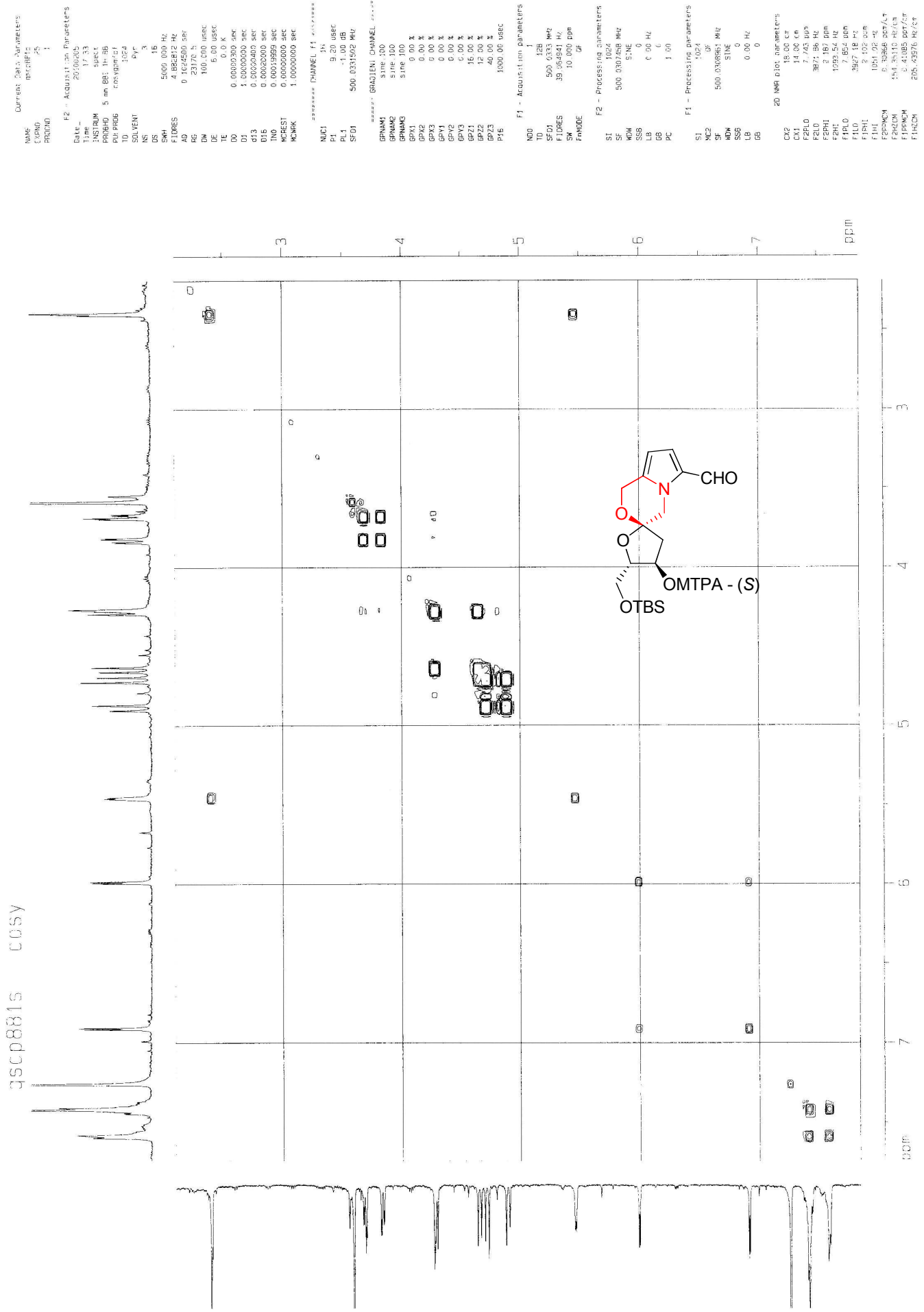
S20. $\quad{ }^{1} \mathrm{H}$ NMR spectrum of $(R)$-MTPA ester of $\mathbf{1 a}$ in $\mathrm{CDCl}_{3}$
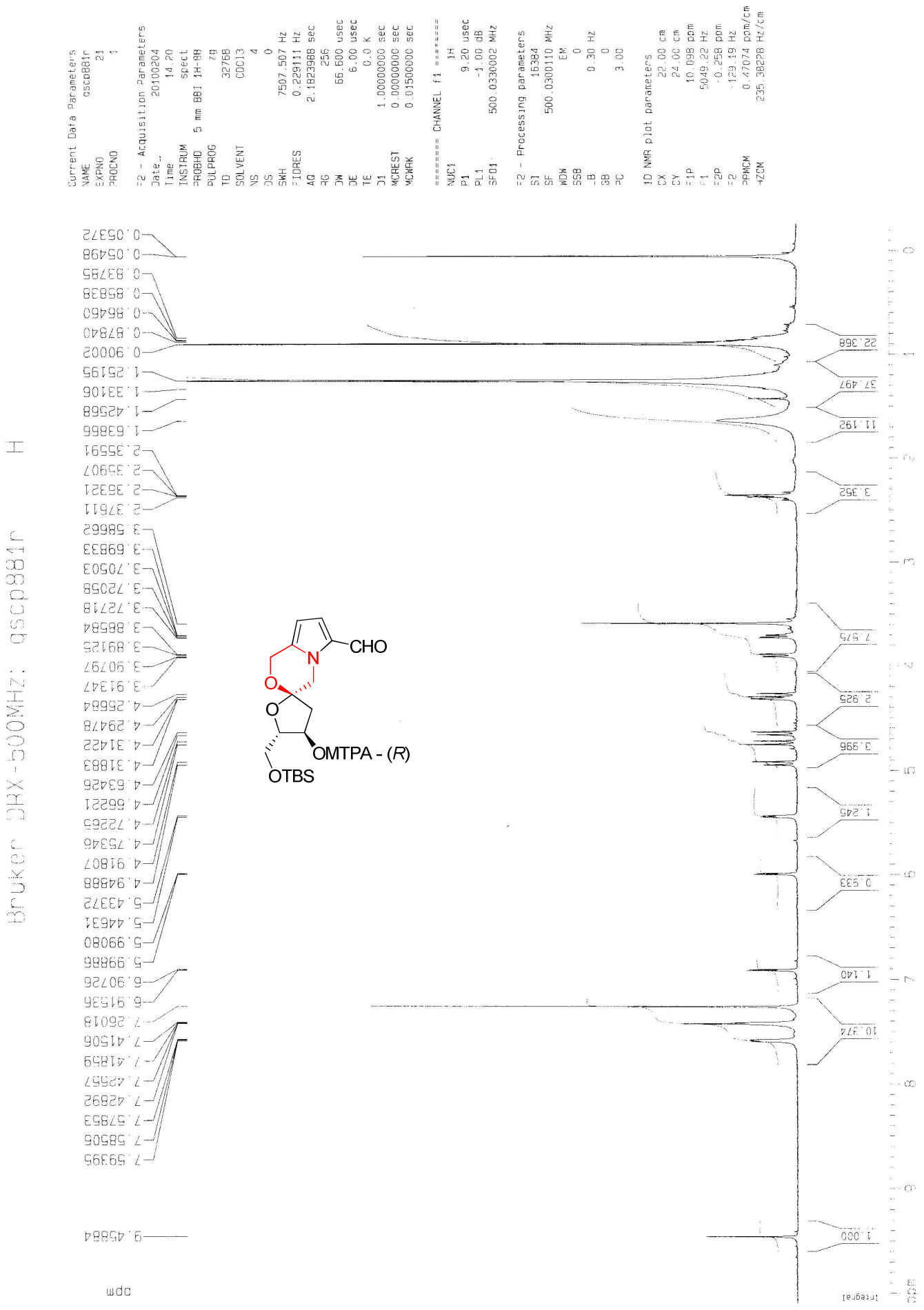
S21. $\quad{ }^{1} \mathrm{H}-{ }^{1} \mathrm{H}$ COSY spectrum of $(R)$-MTPA ester of $\mathbf{1 a}$ in $\mathrm{CDCl}_{3}$

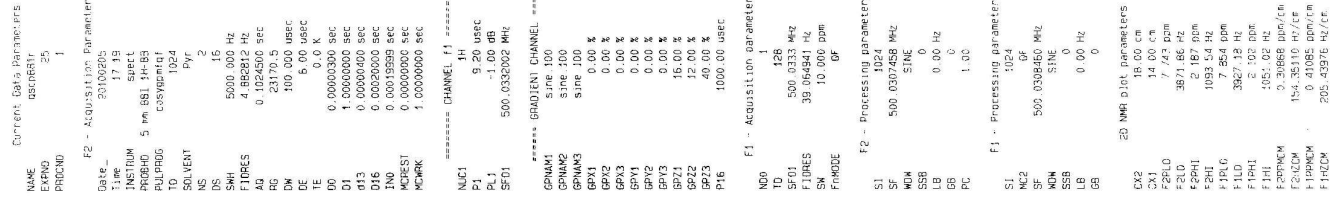

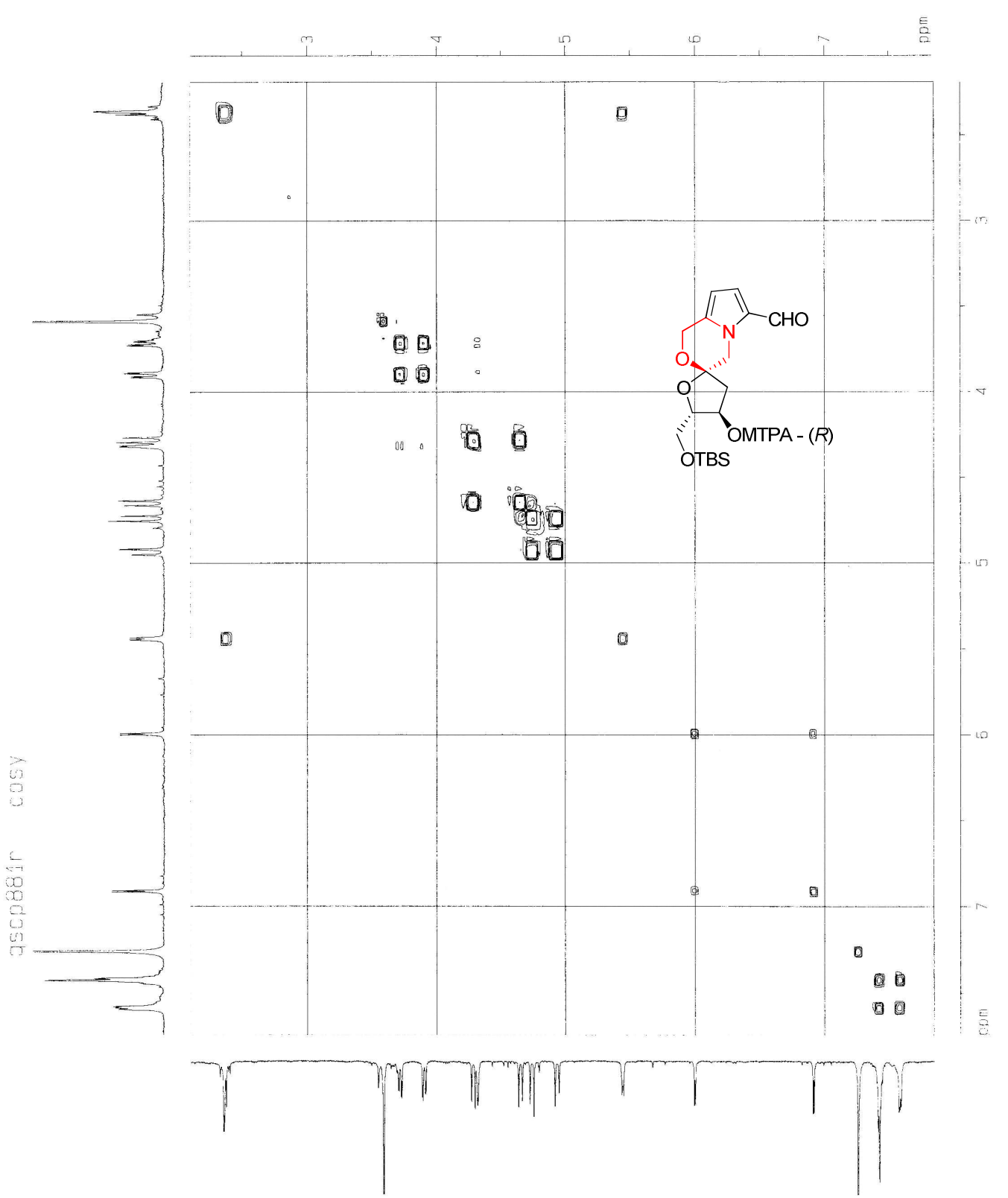

